\title{
Ecological Costs and Benefits of Teak Defoliator (Hyblaea puera Cramer) Outbreaks in a Mangrove Ecosystem
}

\author{
Arun P R ${ }^{1, *}$, Maya V Mahajan ${ }^{2}$ \\ ${ }^{1}$ Environmental Impact Assessment Division, Sálim Ali Centre for Ornithology and Natural History, Coimbatore, 641 108, India \\ ${ }^{2}$ WWF India, Bhav anisagar' Ind ia
}

\begin{abstract}
The Teak defoliator moth (Hyblaea puera) is a well-known pest causing significant economic losses on timber production from teak plantations during their seasonal outbreaks. Apart from Teak, it also attacks an alternative host plant, Avicennia marina, a prominent mangrove tree species abundant along the west coast of India, causing severe and extensive defoliation of Mangroves. However, the ecological role of this pest species in the mangrove ecosystem appears to be complex and is much less understood. Here we report the lesser known ecological aspects of Hyblaea infestation from the Mangrove ecosystem of Thane creek area of Mumbai, Maharashtra, India, based on our field observations. Beyond the apparent feeding damage and defoliation caused by the Hyblaea caterpillars, there are quite a few positive ecological services that these pests are rendering to the mangrove system, especially in the context of mangroves of Mumbai. These include promotion of mangrove diversity, nutrient enrichment and boosting of fishery yield. A possibility of genetic divergence between the Hyblaea populations feeding on Teak and Avicennia is also indicated based on obvious differences in behavioural and life history traits between the populations of this pest in Teak plantations and Mangroves. The paper throws up an apparent conservational dilemma of whether Hyblaea puera in the context of Mangrove ecosystem is a 'pest to be controlled or a species to be conserved'?.
\end{abstract}

Keywords Ecosystem Services, Mangrove Pest, Mumbai, Hyblaea Puera

\section{Introduction}

The mangrove forests along the Mumbai coast (Maharashtra, India) gets affected by the remarkable outbreaks of the moth Hyblaea puera (Order: Lepidoptera; Family: Hyblaeidae). The pest is better known as the 'Teak defoliator' and is primarily a Lepidopteran pest of Teak (Tectona grandis) plantations [1]. The caterpillars of the moth were observed to defoliate thous ands of acres of Mangrove stands en masse along the Thane creek area at irregular intervals over the past several years. H.puera is native to South-East Asia and is mostly resident in Teak plantations. There are several studies reported on the biology[2-6] and management of this pest in Teak plantations $[3,4,7,8$,$] . However$ there is very little information on these aspects from the Mangroves, where this pest is found on an alternative host in Grey Mangroves (Avicennia sp.) and has ingeniously adapted its life-history traits to suit the micro environ mental conditions of the mangroves, which are different from that of the Teak plantations. The outbreak of this pest also causes several beneficial and positive impacts on the ecosystem and

* Corresponding author:

eiasacon@gmail.com (Arun, P R)

Published online at http://journal.sapub.org/ms

Copyright (C) 2012 Scientific \& Academic Publishing. All Rights Reserved associated people's livelihoods. The present paper presents an objective overview of multiple environmental impacts from pest incidences from an ecological perspective, discussing the various potential positive impacts to the system as well of pest outbreaks.

\section{Background}

The observations on the Hyblaea puera outbreaks were made from Vikhroli Mangroves area (at $19^{\circ} 05^{\prime} 47^{\prime \prime} \mathrm{N} \& 72^{\circ}$ 57'00" E) of Mu mbai between 2006 and 2009, along with a study on Butterflies of the area. The mangroves along Thane Creek, Mu mbai regularly suffer fro $m$ the Hyblaea infestation especially during the post-monsoon period. However, the outbreaks vary in intensity with major outbreaks causing near comp lete mangrove defoliation happening only once in few years. Recent major outbreaks were observed in these mangroves in 2006 and 2009. According to the reports from teak plantations of various regions, the life cycle of Hyblaea is generally completed within a month and around twelve generations are possible every year[9]. However there is no comparable information available from the mangroves.

For Hyblaea puera the Avicennia is an alternate host while the Teak (Tectona grandis) is believed to be the primary host. However it appears that even the Teak plants present in close vicinity of the Hyblaea outbreak sites are often spared and 
the pests restrict themselves strictly to the Avicinnia sp. here. Moreover, the Hyblaea puera while in the Mangrove system shows some unique adaptations strikingly different from their counterparts in Teak plantation. For instance, the Hyblaea caterpillars (Figure 1) pupate mostly among the leaf litter on ground in the case of Teak plantations [9], while it pupate strictly on tree branches itself in Mangroves (Figure 2). The life cycle is reported to be the slowest during the post monsoon months in Teak plantations [4,8,9], while same is unlike ly to be true in the Mangroves during this period, since the post monsoon is the outbreak season in the mangroves. There is very little published information available on the biology and pest status of Hyblaea from Mangroves. Only a detailed comparative study can bring out more of these special adaptive traits of Hyblaea in the mangrove system.

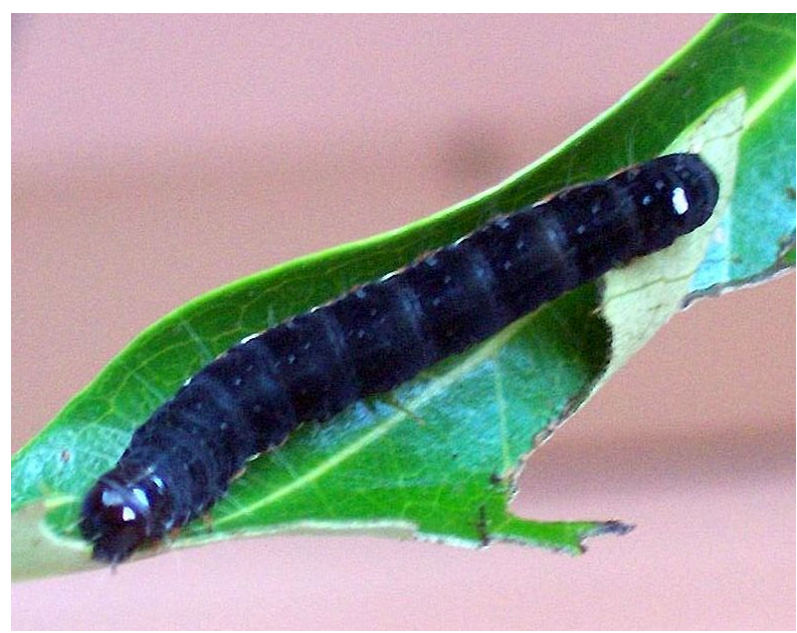

Figure 1. Hyblaea puera, the Caterpillar on Avicennia leaf

In the absence of any historic quantitative data available on the extent of these outbreaks, the relative severity of recent outbreaks cannot be objectively evaluated. However according to the local people the 2006 outbreak was the most severe and was followed by the devastating floods in July 2006. It is not clear how does the flooding of surrounding landscape has a boosting effect on the population of this pest.

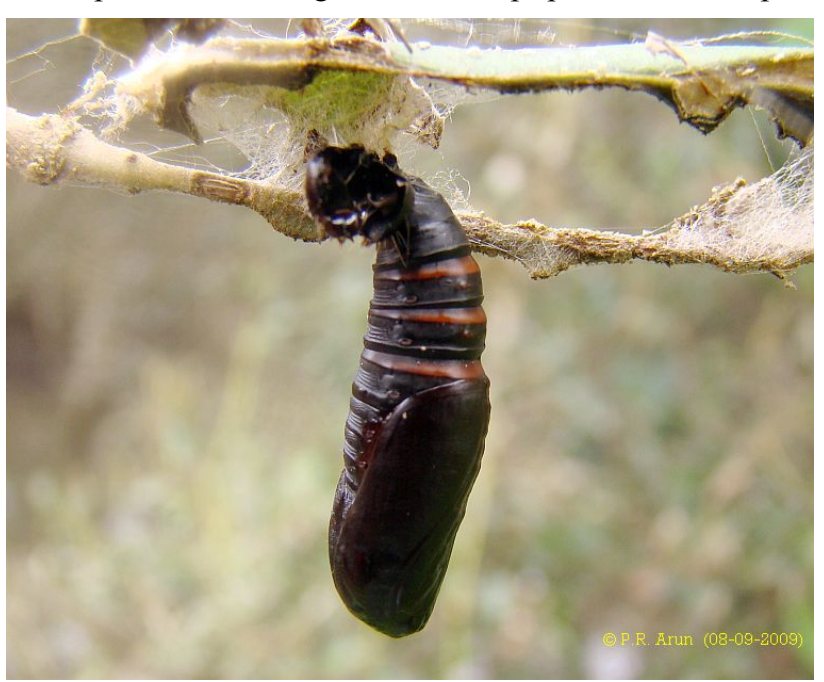

Figure 2. An exposed pupa on Avicennia

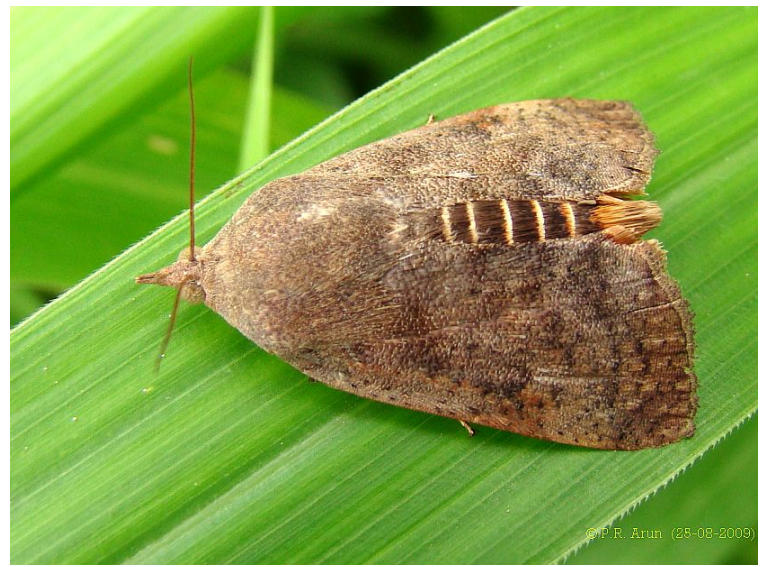

Figure 3. The Adult Moth. (Hyblaea puera)

\section{Ecological costs and benefits}

Outbreaks of this pest are observed immed iately after the pre monsoon showers in late February or early march in Teak plantations of Kerala[10], While in Mangroves it was observed during post monsoon months. Interestingly, the reports suggest that Hyblaea outbreak in mangroves occur always during the transition season between rainy and dry seasons ie. between March and July in Equatorial Brazil[11] and September to January in Mumbai.

It appears that there are diverse ecological impacts on to the system during this pest outbreak. The outbreak usually result in complete defoliation of Avicennia trees, and cause a break in the growth and development of the Avicennia trees, however this is not fatal for the trees except possibly the saplings. Older trees often bounce back with fresh foliage within few weeks. However it is not clear whether it affect the natural recruitment rates by causing any significant mortality of Avicennia saplings. However, apart from this obvious negative impact of extensive defoliation damage to the mangrove trees caused by the caterpillars, there are also several other positive impacts on the system during these pest attacks. This includes promotion of mangrove biodiversity, Nutrient cycling and augmentation of fishery resources.

\subsection{Impact on Biodi versity}

Hyblaea puera caterpillars defoliates only Avicennia sp, the predominant species present in the mangroves of Mumbai region (Figure 4). In fact, the mangroves stands in Mumbai are comprised of more than $95 \%$ Avicennia with very few other mangrove trees. The do mination of Avicennia has resulted in poor abundance and diversity of other Mangrove species. During the Hyblaes outbreak these other mangrove species get a breathing space and conducive environ mental conditions which include lesser competition for space, light and nutrients. Thus these pest outbreak help in establishing other mangrove species and thus promote better diversity of mangroves. Further, it is reported by Mehlig \& Menezes[11] from Brazil that the attack is Severe on 
'monospecific' Avicennia stands, while Multi species areas are much less affected. Monospecific A.germinans stands were completely defoliated, whereas in a mixed forest several A. germinans trees remained unaffected, even in the immed iate neighborhood of infested trees

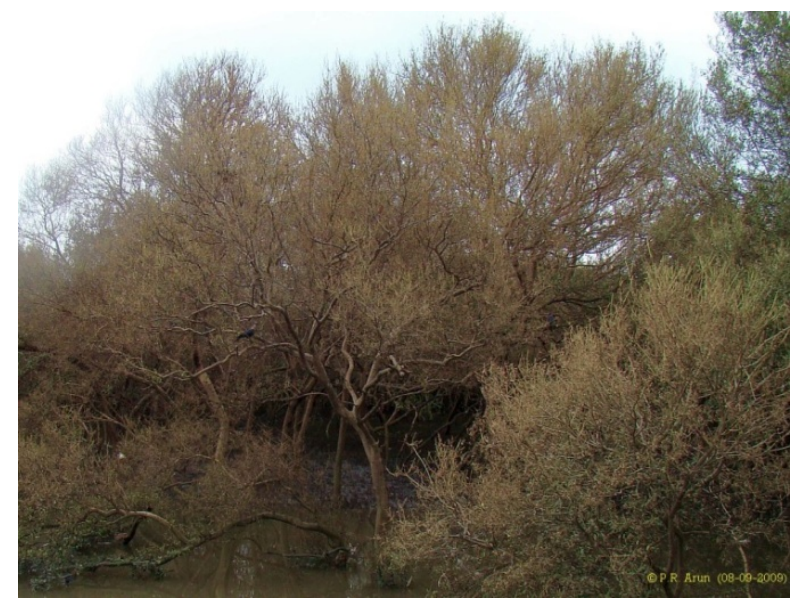

Figure 4. The Avicennia trees defoliated by the pest

It was observed that during the Outbreak seas on, there are large congregations of birds attracted to the affected mangrove areas to apparently feed on the caterp illars. The Egrets, Pond herons and House crows were especially abundant in the mangroves areas infested with Hyblarea. However there is no data available on the preference of these caterpillars by birds as a food source.

\subsection{Impact on Nutrient Cycles}

Enhanced nutrient supply into the system is another major service that this pest outbreak provides to the mangrove system. Huge amounts of leaf litter get 'short-circuited' bypassing the normal cycle. The Avicennia leaves contain tannins that have to normally pass through the slow benthic food chains of mangroves for decomposition. However, During Hyblaea attack, it gets directly transformed to easily available and digestible forms such as caterpillar frass and caterpillars (live \& dead) that enhanced the nutritional availability for various other life forms and enriched the Mangrove soil as well.

\subsection{Impact on Fisheries}

Another significant positive manifestation of this pest outbreak is on the improvement of fisheries resources. Severe in festation years are known for the bumper catch, especially shrimps from the mangrove areas. In Brazil such infestation years are called 'shrimp years'[11]. Because of corresponding bumper catch of Shrimps associated with the pest attack.

\section{Conclusions}

The paper examines the ecological roles played by a Lepidopteran pest species, the Hyblaea puera, during its outbreaks in the mangrove forests of Mumbai region. The Hyblaea outbreak is an interesting ecological phenomenon which raises several unanswered questions on the ecological roles of these seasonal pest outbreaks in the mangrove ecosystems and factors triggering and controlling these outbreaks in Mangrove areas. According to local fisher folk the severe flood situations during the monsoon seas on of certain years might be acting as a trigger in some way for the outbreak. However, long term data is lacking to confirm any such correlation. The Impact of the outbreaks on various aspects of the Mangrove ecosystem such as recruitment \& survival of Avicennia saplings, Light regimes with in mangroves, Bird populations, Nutrient cycles, Biodiversity, Secondary Pests and pathogens and Fisheries also needs to be studied on a long-term bas is for a better understanding of the pest outbreak phenomenon in Mangroves for developing effective monitoring and management strategies.

The totally contrasting ecological niches, seasons and lifecycle strategies adopted by the same insect while using two different host species namely, Teak and Avicennia indicate a possible chance of a genetic divergence between the populations of Hyblaea attacking Teak and Avicennia. This needs to be confirmed through genetic analys is studies. Incidentally it was also observed at Mumbai that some of the Teak plants available in the vicinity were not attacked by the Hyblaea caterpillars during the outbreak season in the Mangroves.

Hyblaea puera in Mumbai mangroves come across as an exceptional kind of pest outbreak that promotes Mangrove diversity, Contribute to the Nutrient cycling, Enhance fishery resources and Provide food sources for Birds. It would require serious long term research and monitoring to objectively weigh the pros and cons of Hyblaea outbreaks in various mangrove ecosystems before we can answer the conservational dilemma of whether Hyblaea in Mangrove system is 'pest to be controlled or a species to be conserved'.

\section{ACKNOWLEDGEMENTS}

We greatly acknowledge the help and encouragement received from Godrej family and Mr. Manek Engineer of Godrej, Vikhroli establishment for kindly consenting for the field studies in the mangrove areas under their control. We are also grateful to Dr. PA A zeez, Director, SACON for the critical suggestions and encouragement.

\section{REFERENCES}

[1] R.D. Katagall, Insect pests of teak (Tectona grandis L.) with special reference to the bio-ecology of the defoliator Hyblaea puera (Cramer)(Lepidoptera: Hyblaeidae), M. Sc (Agri) Thesis. (1991).

[2] M.W. Baksha, M.J. Crawley, Relative preference of different host plants to teak defoliator, Hyblaea puera 
Cram.(Hyblaeidae: Lepidoptera) in Bangladesh, Bangladesh Journal of Forest Science. 24 (1995) 21-25.

[3] M.W. Baksha, M.J. Crawley, Population dynamics of teak defoliator, Hyblaea puera Cram.(Lep., Hyblaeidae) in teak plantations of Bangladesh, Journal of Applied Entomology. 122 (1998) 79-83.

[4] J. Loganathan, P.M. David, Population dynamics of teak defoliator, Hyblaea pura in commercial teak plantation, Madras Agricultural Journal. 85 (1998) 557-561.

[5] D. Muraleedharan, V.K.K. Prabhu, Hormonal influence on feeding and digestion in a plant bug, Dysdercus cingulatus, and a caterpillar, Hyblaea puera, Physiological Entomology. 6 (1981) 183-189.

[6] N. Rouchoudhury, K. Joshi, Larval Feeding Habits and Moulting Behaviour of Hybiaea Puera Cramer on Teak, Advances in Forestry Research in India. (1988) 228.
[7] S. Chattopadhyay, Observation on the feeding habit of the teak defoliator, Hyblaea puera Cramer (Hyblaeidae: Lepidoptera)., Journal of Interacademicia. 4 (2000) 183-185.

[8] K.S.S. Nair, The Teak Defoliator in Kerala, India, 1988.

[9] Javaregowda, Studies on the seasonal incidence, biology and management of Teak Defoliator, Hyblaea puera Cramer (Hyblaeidae: Lepidoptera), UNIVERSITY OF AGRICULTURAL SCIENCES, 2005.

[10] K.S.. Nair, V.V. Sudheendrakumar, The teak defoliator, Hyblaea puera: Defoliation dynamics and evidences for short-range migration of moths, Proceedings: Animal Sciences. 95 (1986) 7-21.

[11] U. Mehlig, M.P.M. Menezes, Mass defoliation of the mangrove tree Avicennia germinans by the moth Hyblaea puera (lepidoptera Hyblaeidae) in Equatorial Brazil, Ecotropica. 1 (2005) 87-88. 